\title{
There's Something about Mary: Challenges and Prospects for Narrative Theodicy
}

\author{
Jill Graper Hernandez \\ Central Washington University
}

\begin{abstract}
This paper explores the constraints of narrative theodicy to account for the misery of the powerless and uses Mary of Bethany as a case study as evaluated through the early modern theodical writings of Mary Astell and Mary Hays. Eleonore Stump has pointed out that Mary of Bethany's misery is interesting because it is so personal; it results from losing her heart's desire. But, Mary of Bethany's case fails as narrative theodicy because it cannot (unlike other cases, such as Job) sufficiently demonstrate the power of God in situated expressions of suffering, speak to plight of the powerless, nor put the sufferer in a stronger epistemic position. Astell and Hays provide a solution for the problem of lived experiences of systemic oppression for the project of narrative theodicy (it must be for and about suffering), and in so doing, remind us of the continued significance of their work to the philosophical canon. To succeed, narratives used for theodicy must speak directly to the plight of those who suffer, and must allow the powerless, miserable, unprivileged, and oppressed to have access to religious knowledge of the relationship between God and the one in misery, the one powerless.
\end{abstract}

A recent trend in analytic philosophy of religion explores the theodical ability of narratives. ${ }^{1}$ Eleonore Stump (2001 and 2010), for example, argues that narratives can be more effective as theodicy than logical arguments, especially to communicate theological knowledge which evades propositional representation. The meaning of suffering in a world in which God exists can be more successfully conveyed by narratives that relate to lived, concrete experiences of suffering. Further, connecting theodicy to concrete harms alleviates a worry for feminists that analytic philosophy's theodicies are too abstract and disconnected from people's actual lives to make a meaningful impact outside of the circle of scholars who already believe in

*Special thanks to Amber Griffioen, Lacey Hudspeth, Julia Lerius, Gary Ostertag, Christina Van Dyke, and other participants in the 2018 "Expanding the Canon" International Conference, as well as anonymous referees for the Journal of Analytic Theology, all of whom made this paper better. 1 Yandell (2001) was significant to kick off the conversation, and has fueled work in literature, philosophy, and religion, including a recent monograph, Ziegler (2017) and PhD. dissertation, Lindley (2016).

Journal of Analytic Theology, Vol. 9, Summer 2021 10.12978/jat.2021-9.090811070425

(C) 2021 Jill Hernandez • (C) 2021 Journal of Analytic Theology 
theodicy's efficacy. ${ }^{2}$

This paper challenges narrative theodicy generally, and the efficacy of Stump's narrative theodicy specifically, by exploring the constraints of narrative theodicy to communicate that God is present in our suffering, with particular focus on the biblical case of Mary of Bethany (who is identified by Stump as a model). Mary of Bethany's grief is interesting for Stump because it is so personal; it results from losing her heart's desire (Stump, 2010, 382-3). Mary's story is from the perspective of the powerless, but because her suffering is banal, tied to her personal friendship with the person of Jesus, and does not lead to brokenness, the story may fail to communicate divine perfection to someone suffering today. To salvage Mary of Bethany as narrative theodicy, the paper shifts to introduce the views of two other Marys (Mary Astell and Mary Hays, feminists in the early modern period) to clarify that contemporary theodicy should demonstrate divine perfection to those who experience real suffering from "evils in the amounts and of the kinds and with the distributions of the sort found in the actual world"3.

Framing narrative theodicy through the lens of early feminists who shared commitments to eradicating systemic harms and demonstrating the love and power of God helps show that all is not lost for the project of narrative theodicy, nor (perhaps) for the story of Mary of Bethany as narrative theodicy. To succeed in the way Stump wants them to (so, to convey non-propositional truth about divine perfection despite inordinate suffering in the world), narratives used for theodicy should speak to the plight of those who struggle, put the oppressed in a stronger epistemic position, and concretely engage with the position of the powerless. Relying on Astell and Hays provides an analytic feminist framework to define the contours for narrative theodicy to do this today.

\section{The Case for Mary of Bethany as Narrative Theodicy}

Stump takes the narrative accounts of suffering in the biblical stories of Job, Samson, Abraham, and Mary of Bethany to justify the view that God has morally sufficient

\footnotetext{
2 Those who are adept at conversing through traditional analytic arguments about the problem of evil, the narrative structure of a theodicy might give pause. Stump's use of narrative, however, isn't meant to change the function of theodicy as a tool to demonstrate the compossibility of the existence of God in a created world in which there is evil. Instead, she believes that narratives can include all of the features of theodicy as well as all of the elements of the problem of evil and better address the phenomenological experience of a sufferer, "What does it take to redeem suffering - to defeat evil, as philosophers say? It is not always easy to say in the abstract. How would we adjudicate an answer to this question? What would count as evidence for our answer? How are we to discuss the question? What looks perplexingly blank in the abstract has handholds for our thought when we think about the question in connection with a story" (2010, xviiii).

${ }^{3}$ Marilyn Adams $(1999,14)$. Adams was convinced that philosophy must respond to feminism's call for concretely-engaged theodicy, “[Theism's] propensity for generic solutions-our search for a single explanation that would cover all evils at once-has permitted us to ignore the worst evils in particular and so to avoid confronting the problems they pose"(3). A call for philosophers and theologians to pay attention to concrete suffering does not require particular philosophers to attend to horrendous evil, but it does require philosophy and theology to address it.
} 
reasons within the narrative for allowing suffering. Stump believes that the experiences captured in these narratives help us to know that God and evil can be co-present in the world. Stump's assiduous work to identify, exegete, and link biblical narratives to contemporary theodical projects makes hers a solid candidate for a discussion on the contours of narrative theodicy. This is especially true because Stump is the only philosopher of religion to date who takes the story of Mary of Bethany seriously as a candidate for narrative theodicy. Stump's choices of narratives are varied and interesting, at least because the theodical narratives of Job, Abraham, and Samson offer epic displays of divine providence in striking opposition to the humble character of Mary of Bethany. Job, who suffers by losing all his children and material wealth, was not just rich before he suffered; Job 1:3 tells us he was the greatest man in the East (and recaptured his wealth after his period of trials). Abraham, whose "leap of faith" in giving up his son Isaac for sacrifice set him up for tremendous grief, was also the "father of nations" whom God promised would be blessed among nations (Gen 12:2-3) and was given enormous material wealth (Gen 24:35). Samson was set apart by God before birth as a Nazarite, as someone who would dedicate himself to serving God his entire life and be blessed as a result (Judges 13: 7, 24-5). He squandered his enormous physical strength as a result of lust and suffered until his dying day, when he asked God to return his strength to him one last time to kill the Philistines who had gathered to mock him. Mary of Bethany, sister to Martha and Lazarus, stands out among Stump's examples of narrative theodicy. ${ }^{4}$ Mary is perhaps remembered best for being scorned by her sister for sitting at the feet of Jesus rather than laboring in the kitchen. Stump thinks Mary of Bethany is an exemplar of a person who suffers through shame, the death of her brother, and then the death of Christ. (Minimally, Christ was a beloved family friend. Stump believes that he represented something more to Mary, one whose death resulted in losing her heart's desire (the subject of Chapter 12 of her book). Regardless of the extent of her care for Christ, Mary's suffering ranged from loss of a loved one to loss of faith.)

There are stark epistemic and power differences between Mary of Bethany and Stump's other exemplars for narrative theodicy. There is no evidence that Mary of Bethany was wealthy. She did not have social power, since she was the object of

\footnotetext{
${ }^{4}$ It should be noted that there is some disagreement about when a given New Testament "Mary" is Mary of Bethany. Mary of Bethany is probably not Mary Magdalene, for example. (Yet, there is even debate on this topic. See Kent, 2010.) One of the ways to discern between the Marys is to compare the Gospels' direct accounts of Mary of Bethany against those that likely reference her and her family. John and Luke agree that Mary: a) loved Jesus, b) discussed Christ's teachings with him, c) was rebuked by a disciple for an audacious display of affection for Jesus, d) was defended by Jesus, e) anointed Jesus, and f) was commended by Jesus for her priorities and choices. (This list is derived from Beavis's excellent work, 2013, 755. The following are the scriptural references for the corresponding stories told by John and Luke: a) John 11:5; cf 12:1-8, Luke 10:42, b) John 11:28-33; Luke 10:38-42, c) John 12:4-5; Luke 10:40, d) Luke 10:42; John 12:7-8, e) Luke 10:38-42; John 12:18; f) Luke 10:42; John 12:7-8.) Stump concurs with Beavis that Mary of Bethany was the unnamed, scorned woman who anoints Jesus' feet in the Gospels of Mark, Luke, and John. Reading the texts together underscores Mary's significance to the work of Christ—not only is she praised for "doing what she could", but she also sets Christ up to foretell his burial (Baffes, 2016, 84) and motivates his disciples to "move beyond the prosaic concerns of their daily lives" (Platt, 1977, 30).
} 
scorn for anointing Jesus's feet and (separately) for choosing not to assist in menial tasks when Jesus was teaching. She did not hold a position of spiritual authority, especially as an unmarried woman, which distinguishes her from Job, Abraham, and Samson. Her story is told by men, and her suffering also differs from Stump's other examples in at least two ways. First, she suffers ordinarily. Mary's grief comes from standard certainties of real-life relationships (such as sibling strife and the death of loved ones). The rather mundane grief still cries out for a theodicy, Stump believes, "Digging into the context of Mary's story reveals her theodicy. Ordinary heartbreak requires a theodicy whenever the sufferer loses her faith as a result of her suffering" (2010, 312). The banality of Mary's suffering stands in contrast to Job, who has become the paradigm case of human suffering, and to Abraham, whose theodical leap of faith is its own philosophical paradox, and to Samson, whose misery extended from his Herculean strength to his Dionysian sin. Stump thinks Mary's suffering uniquely supports the project of theodicy by using ordinary hurts to demonstrate the love of God during suffering, because most of the world's suffering "is ordinary heartbreak and shame" $(2010,312)$. Mary's story resonates with marginalized people in ways that stories of epic Old Testament heroes do not, at least because hers is the story of an ordinary person who suffers ordinary troubles.

Despite the ordinariness of her struggle, Mary of Bethany is viewed by Stump as an example of theodicy: in particular, when Mary anoints Jesus's feet (and is subsequently scorned by the disciples for extravagantly wasting expensive oil), Stump believes Mary has a loss of faith that justifies a need for theodicy. On the surface, to the disciples, Mary's waste broke the law of almsgiving to the poor (Platt, 1977, 30). But, her tears were symbols of her love for Christ and her despondency at losing another loved one for the sake of providential purposes. Like countless others who wonder where God is in their suffering and loss, Mary of Bethany experiences powerlessness against the providence of God and a feeling of being abandoned by God. To Stump, her heartbreak and isolation resemble a crisis of faith for those who question divine perfection and presence during their suffering, and so her story seems like a suitable candidate for narrative theodicy.

To weigh Mary of Bethany as a case for narrative theodicy, we need to understand how narratives function as theodicy differently than analytic arguments. The goal for narrative theodicy is theodicy, but as narrative, the form and results are richly different than those expected for logical proofs about the problem of evil. Narrative theodicies can relate persons to their beliefs, their beliefs to experiences, and require that their experiences have existential meaning that is consistent with their beliefs (or, their beliefs must change). For narrative theodicy to be persuasive, it must communicate to those who suffer. Narrative theodicies face a challenge not faced by non-narrative theodicies, then, in that the concepts, situations, and characters within a story might not resonate with individuals who find themselves in relevantly similar situations. The characters may be too ideal or iconic to resonate (like Abraham, Job, and Samson) or they may require too much imagination for us to relate to (like Mary of Bethany). By embracing the relatability of the narrative voice, the reader/listener can be empowered to respond to the narrative. If the narrative's characters are relatable, it can create the conditions under which confrontations of the victim's beliefs about the existence of God in the presence of suffering can occur. 
The characters should be relatable to those who suffer, but the narrative should also resonate with the isolation and brokenness that those who suffer endure. Even for seemingly banal experiences of grief, the narrative should expose the level or degree of brokenness of the character's belief in divine goodness or power. As Stump suggests, the suffering should result in a loss of faith. Where suffering is inescapable, narratives can reveal that healing is possible, at least by transferring grief from the sufferer onto God, who will stand with the sufferer in her inescapable moment (Abbott, 2011, 125). On this point, the Mary of Bethany story appears to break down as narrative theodicy. The hearer of the story can imagine losing a loved one, a dear friend, and being publicly humiliated for her display of care. But, a good bit of speculation is required to conclude that Mary is broken from her loss, especially broken in a way that leads to a loss of faith or belief. In Luke's account, for example, Mary's act of anointing Jesus is told as a story of Christ bestowing gifts of love and forgiveness on Mary (rather than Mary losing, she is restored). Instead of experiencing brokenness, "in humility, gratitude, and love, this woman dares to kneel at the feet of Jesus, as the prophetic witness, to anoint and welcome the Messiah whose power is known in forgiveness" (Platt, 1977, 34-5). At least if non-canonical reports and church traditions about what became of Mary of Bethany resemble truth at all (in which case, she is remembered as a "disciple, apostle to the apostles, symbol of the church, new Eve, participant at the Last Supper, myrrh-bearing witness to the empty tomb and resurrection, administrator, deacon, miracle worker, baptizer, eucharistie minister, missionary, preacher, Gnostic illuminata, and martyr," Beavis, 2013, 755) then Mary was not undone by her grief and (perhaps most relevant here) did not endure persistent misery and loss of belief which precipitate the need for theodicy.

Relatability is only one factor in a narrative's success as theodicy. It isn't enough for a story about grief (and a subsequent crisis of faith) to be relatable or account for divine perfection. Pain is never abstract, it is always incarnational and personal. ${ }^{5}$ So, narrative theodicies should bring the sufferer to healing, at least as it relates the personal nature of her suffering to her belief in God. Abbott explains,

At their core, narrative theodicies are tales of life inescapably lived, separated from oneness and love, and insist that the way to have a life worth living is for a redeemer or healer to contain and detoxify the projective identification without retaliation, and for the redeemer or healer to lead one to an acknowledgement of the damage done to and by oneself. The past is important but the goal of life is not the veneration of the past but liberation into a free future. The ethical core is reparation. $(2011,126)$

There are, then, at least three reasons to doubt the case study of Mary of Bethany can effectively serve as a narrative theodicy. First, although Mary of Bethany is relatable in the ordinariness of her grief (she suffers humiliation and the loss of

\footnotetext{
5 Paul Tillich once wrote, "Only a person can heal a person" $(1959,131-132)$. If so, narrative theodicies can heal by concretely relating the sufferer to the perfection and presence of God. Theodicies that heal are those in which the person of God is made real to the sufferer.
} 
family and friends like most people do in the span of a life) her character is not relatable in the extraordinariness of her theodical experiences. As a New Testament character, Mary already has an epistemic advantage over anyone today because of her friendship with Christ. It is hard to relate to Mary of Bethany when it comes to her friendship with someone who, according to Luke, both forgives her sin and gives her the ability, as a result of that forgiveness, to love ten times more fully (Luke 7:41-47, Platt, 1977, 133). Differently than the more-relatable writer of Hebrews, Mary's faith was not in what was unseen, because she was able to see Jesus. Stump concurs, "The shame of Mary of Bethany is healed, partially and then wholly, in her relationship to Jesus, who is recognized in the story as the son of God" $(2010,397)$. If Mary did not need faith like ours, then her story could fail to communicate that God will show up for the contemporary sufferer. It is difficult to relate to her unmediated relationship with Christ.

The second reason to think Mary's story is not a strong case for narrative theodicy is that the arc of the stories about her in the gospels does not evince the isolation and brokenness of suffering we would expect from narrative theodicies. We do not have to take up Marilyn Adams's call for theodicy to speak to horrendous evils to mean that all theodicies must do so. Yet, for grief to yield a need for theodicy, it needs to (as, mentioned earlier) generate a loss of faith. Does Mary's banal suffering generate a need for theodicy? Stump recognizes a "mystery" behind Mary's suffering, but she ultimately concludes that "the misery of being unwanted, shamed, and heartbroken is shown in the story of Mary.... All the modes of suffering are here, even if many of the species are missing" $(2010,373) .{ }^{6}$ Granted, whether Mary's suffering qualifies as the genre of suffering theodicy typically focuses on, the worry might be less with the story of Mary of Bethany specifically and more with narrative theodicies of its type (those that attempt to provide a theodical function for stories of ordinary, rather than horrendous suffering). But, in Mary's case, the modes of suffering seem to be missing along with the species. It isn't just that Mary's suffering is banal. We can imagine that she would be heartbroken at the loss of her brother and friend (both of whom, not incidentally, were raised from the dead). But it is difficult to imagine that these losses cause the loss of faith that Stump thinks it does, and that theodicy addresses. Stump asks us to consider that Mary and Martha wanted "to matter to Jesus as part of their heart's desire," and when Jesus did not immediately heed their call to come to Bethany to heal Lazarus, it marked the "break in the relationship between Mary and Jesus, and Mary's heartbreak, that made the bond stronger by the end of the story" $(2010,351,353)$. With some imagination, it is possible to see Mary in the way presented by Stump-as losing faith. But, we have equal or stronger reasons instead to suspect that Mary's heartbreak was because Lazarus had died and Jesus could have prevented it, "Lord, if you had been here, my brother would not have died" (John 11:32). Like Stump, we can imagine Mary's grief results from not feeling loved by Christ, but as readers, we actually have to imagine

\footnotetext{
${ }^{6}$ The "modes" of suffering used by Stump are those that she thinks are represented by the four narratives separately: "In their stories we find the pain and agony of the innocent victim, the evil of self-destruction, the heartsickness of losing what one loves the most, and the misery of being unwanted and shamed" $(2010,375)$.
} 
$i t$, because the stories themselves do not demonstrate that Mary feels that her relationship with the one she anointed was broken, nor do they demonstrate she lost her faith. Rather, amidst her suffering Mary's first impetus when physically confronting Christ was to confirm her belief in Christ's abilities. Upon seeing him arrive late to their home, Mary affirms her belief that if Jesus had been present in Bethany, Lazarus would not have died. We would expect that if Mary had lost her faith, we would have at least one report of Mary's disbelief. ${ }^{7}$

Finally, Mary of Bethany's story fails as narrative theodicy because it cannot sufficiently demonstrate the power of God in situated expressions of suffering. If Stump is right, and Mary of Bethany's story can serve as theodicy, it should reveal an answer to why God permitted Mary's particular, situated suffering. A feature of her banal grief is that it is not relieved by a dénouement of divine providence to Mary herself. If there are not strong reasons to believe her grief caused a lack of faith, it becomes more challenging for her story to demonstrate that God's power restored Mary's faith. That isn't to say that God's power is not a part of Mary of Bethany's story, especially in the story of Lazarus, in which Jesus is moved to tears as a stark expression of his love for their family (John 11:33-36). The resurrection of Lazarus, preceded by Mary's anointing of Jesus, were both followed by the resurrection of Christ-arguably the most vivid possible display of divine power. God's display of providence to Mary of Bethany is indistinguishable from God's providence to the world through the death and resurrection of Christ. To be sure, this is exactly Stump's view: through divine love and power, the sufferer recoups what was lost and gains something "more worth having than what she originally hoped for" (2010, 473).

There is one sense in which God's care could have been to Mary specifically. Jesus told his disciples that, as a result of Mary's expensive gift during the anointing, she would be memorialized wherever the gospel is spoken (Matthew 26:13). Perhaps the fact that, millennia later, we are thinking carefully about Mary's story stands as proof that God's power was demonstrated particularly to her. The sequence of events surrounding Mary of Bethany's story, however, is fundamentally about divine power amid Christ's suffering, and not Mary's. Mary suffered (as Martha did) when her brother died and Jesus was not present to save him. Their emotional response led to one of Jesus's own (indeed, when Mary and Martha sent for Jesus, they said, "Lord, behold, he whom You love is sick," John 11:3), and his power was on full display when he resurrected Lazarus from the dead. The result of the experience was that many of the Jews who came to mourn with Mary ended up believing in Jesus (verse 45). In both Mary moments, (the anointing of Christ, which served to announce the reign of Christ as king) and the resurrection of Lazarus (which served to prefigure Christ's own death and resurrection and prove his ability to defeat death), the power of God silenced the grief that Mary experienced. The miracles revealed divine providence to the world and were only contemporaneous

\footnotetext{
${ }^{7}$ We could infer from the Lazarus story that Mary's belief is limited. She doesn't, after all, ask Jesus to raise her brother from the dead. Yet, the limits of Mary's belief are not indicative of a loss of belief. They are, instead, a representation of the limits of all believers, who are told to have faith the size of a mustard seed to move mountains.
} 
in time with Mary's suffering. As narrative theodicy, the story of Mary of Bethany appears to fall short.

\section{Other Marys and Challenges for Narrative Theodicy}

Whether Mary of Bethany can be salvaged for theodicy in part depends on deepening our understanding of what to expect from narrative theodicy. Narrative theodicy could be an important tool in analytic feminist philosophy of religion, especially because of its ability to engage with concrete evil. Early British feminists were especially concerned about how to understand the suffering of women that came from systems of oppression (for example, from their explicit exclusion from politics, the church, and the academy), concerns which resonate with contemporary feminists who think the problem of evil is a phenomenological, existential problem more than a logical one. Engaging with systemic suffering brings the philosopher of religion closer to tying the problem of evil to lived suffering, as contemporary feminists would like. Bat-Ami Bar On, for example, comments, "One stops witnessing when one abstracts so much and gets away from the phenomenological experience of the suffering of real people. Abstractness undermines the work on...which a spectator depends in order to connect to embodied people in pain" $(2007,196)$. Some of the best examples in philosophy of religion of linking the problem of evil to concrete suffering come outside of contemporary philosophy and theology. Two other Marys in the history of philosophy-early modern scholars Mary Astell (16661731) and Mary Hays (1759-1843)-prefigured Bar On's view that philosophy should be, fundamentally, about the actual realities of those who suffer; but both Astell and Hays were also theists who spoke to the plight of women through a situated sense of suffering. Because their scholarship speaks to concrete and systemic suffering and is concerned with explaining the goodness of God in the stories of suffering they tell, Astell and Hays are excellent candidates for those interested in making narrative theodicy a viable tool in contemporary analytic philosophy of religion. In her work, Astell argued that "Christian philosophy" (so, theodicy ${ }^{8}$ ), should explicate truth about suffering and its source, should reveal truth about the problem of evil, and should place the oppressed in a better epistemic position than they were prior to the theodicy. The powerful (i.e, those who were privileged to be in positions to communicate stories that others would hear) typically do not concern themselves with the plight of the powerless (i.e., those for whom narrative theodicy would be personally efficacious). To find the goodness of God in the stories of sufferers, Hays also believed that narratives must provide a path to rectify systems of injustice as they are experienced, a vision for eschatology, and an account of divine perfection.

For Astell, a challenge for any narrative theodicy that could speak to suffering women is that privileged men were those who were socially empowered to write

\footnotetext{
${ }^{8}$ Neither would use the term "theodicy," which came in vogue after Leibniz, but both have a rich philosophy of religion and engage in arguments about the compatibility of God's presence in a world where there is horrendous evil. See, for example, Hernandez (2016).
} 
the stories of women, "For if any histories were anciently written by women, time and the malice of men have effectively conspired to suppress them" 1696, 23). ${ }^{9}$ Astell's skepticism about men's inclination and ability to tell the truth about what women suffer extended to scriptural accounts, which were also all written by men. If "time and malice" conspire against historical narratives to accurately depict women's suffering, then time and malice could also conspire against adequately capturing women's experiences in scripture. She did not think that men who were in power were passively silencing the testimony of women and the oppressed; those in academia and the church were actively suppressing women's voices, "The men by interest or inclination are so generally engaged against us, that it is not to be expected, that any one man of wealth should arise so generous as to engage in our quarrel" $(1696,3)$. Astell's issue with the powerful and wealthy is centrally about their role in silencing women's experiences, which amplifies evil's impact on women as spiritual beings. Women disproportionately were among those who were oppressed, and Astell recognized the further complexity of giving voice to the voiceless: those who are oppressed must rely on those who are in power to have their stories told. In her 1697 A Serious Proposal to the Ladies Part II she cheekily wrote,

"Only let me beg to be informed, to whom we poor Fatherless Maids, and widows who have lost their Masters, owe subjection?....But whoever he be that thus happens to become our Master, if he allows us to be Reasonable Creatures, and does not merely compliment us with that title, since no man denies our readiness to use our tongues, it would tend, I should think, to our Master's advantage, and therefore he may please to be advised to teach us to improve our reason." (48)

The "subjection" language leaves no room for interpretation. Unmarried women were without masters until consigned through marriage. If things went well for the woman, her spouse would believe she was intelligent and afford her with opportunities for personal growth. But, woman's good fortune at being married to a man who considered her intelligence to be valued really is only a matter of luck. Women are caught in the dilemma of having to trust men to listen to them (although men frequently used their status in the home to oppress women), and then to truthfully convey their narratives to audiences who already were inoculated against hearing them.

\footnotetext{
${ }^{9}$ For this paper, all early modern spelling and stylistic conventions have been removed. As a note of interest, there has been a recent conversation about whether this text, "in a letter written to a lady/by a lady" was authored by Mary Astell, or Judith Drake (a contemporary and friend of Astell). Until quite recently, the Essay was attributed to Astell. Doubt has been cast due to an inscription recently found on a 1741 catalog by the publisher Edmund Curll, which indicated it was written by "Mrs. Drake, probably a sister of Dr. James Drake, who attended to the publication of the pamphlet". For more information, see Iowa State University's "Cardinal Tales" blog of the special collections, https://isuspecialcollections.wordpress.com/2019/03/26/rare-book-highlights-an-essay-indefence-of-the-female-sex/. Typical citation protocol lists both Astell and Drake as authors.
} 
It may be difficult to remember that not so long ago, a woman's status was completely contingent on her relationship to men. One hundred years after Astell, the same social gender dynamics remained when Mary Hays penned A Victim of Prejudice, an enduring (though shocking) novel about female powerlessness against rape, political oppression, and silencing. In the 1790s, "women were still defined from the standpoint of men and in terms that served male interests. In its extreme form this definition led to a conclusion that women and their bodies were used for ends which were contrary to their own" (Oliver, 2007, 31). In Victim, Hays told the story of Mary Raymond, an orphan who (similar to the "Fatherless Maid" Astell mentions) was cared for by Mr. Raymond until his death, upon which she was kidnapped and raped by a rich landowner who had unrequited designs on Mary. The book is considered to be an early feminist work for a number of reasons, not the least of which is that Hays rejected the typical rape trope of the age (in which the heroine succumbs to the rapist in a consummation of marriage-or, conversely, ends up dying or in ruin because of her perceived loss of virtue $)^{10}$. Ian Ward explains how, as narrative, Hays's depictions viscerally captured the lived experiences of suffering within the period, and sent an unambiguous message to women, "The rape of Mary Raymond, and more particularly still the ensuing evocation of feelings of horror and self-loathing, are unsparing. Most stark, however, is the dawning sense of impotence and abandonment; the realisation that against the prejudice of society and its legal institutions, and against the crushing contempt of her violator, Mary is powerless" $(2009,117)$.

The systemic nature of Mary Raymond's suffering - that it came through social and legal prejudices that validated the legitimate power of her rapist and invalidated her claims to personal and moral rights-is relevant to the issue of whether narrative theodicy can sufficiently relate to the sufferer. If the powerful rarely hear (or properly explain) the perspective of the powerless, it would have been reasonable for both Astell and Hays to abandon confidence in a theodical-type project for their own work. Yet, neither did. Rather, they articulated a need for narratives that contemporaneously resonates with Stump's desire to communicate non-propositional truth about the experiences of those who grieve. Hays tackled the need directly. When she raised the question, "Is there any power capable of counteracting the benevolent designs of the Deity?," she reminded us that theodicy risks disbelief in God's existence and power: "be cautious how you proceed, lest by robbing the Supreme Being of his attributes, by which alone we can form any idea of his nature, you incur the suspicion of Atheism. Infinite power, and infinite prescience imply all I mean to assert, and there is no getting rid of this argument, without admitting still greater incongruities" $(1694,168)$. Astell, for her part, ${ }^{11}$ insisted that women have access to education and use reason to philosophically contend with faith and oppression, in an early moment of feminist philosophy of

\footnotetext{
${ }^{10}$ See Oliver, 31-39.

${ }^{11}$ Astell has been sometimes criticized for a too-conservative view of women that could facilitate further suffering (Perry 1986, for example), for beliefs which included that women should seek truth but when they couldn't obtain it, they could adopt her view: "as for me I am safer in my Obedience, than I could have been even with Truth in a disorderly way" $(1705,34)$.
} 
religion, "She is, it may be, taught the principles and duties of Religion, but not acquainted with the reasons and grounds of them; being told 'tis enough for her to believe, to examine why, and wherefore, belongs not to her" $(1694,16)$. Whereas "groundless instruction" ensures that women only have ornamental value, women should develop philosophical reasoning and moral wisdom to help them navigate evil, pain, and sin. To properly defend faith, and its role in the face of suffering, women need to learn how to reason about faith rather than merely be taught what to believe. Narratives can and should be a part of the sufferer's tools to do so, as long as narratives have the proper features to serve as theodicy.

\section{Contours of Successful Narrative Theodicies}

Read together, Mary Astell and Mary Hays provide a framework for feminist conditions on narrative theodicies today. Their work shows that narrative theodicies can be rooted in the concrete, tell truth about actual injustices in the world experienced by those on the margins, and provide meaningful hope for changing social, religious, and political structures that cause those who are in misery to question the existence of God. For feminist philosophers of religion, their guidance can help structure effective narrative theodicies to tell the stories of those who are voiceless and ignored, and so to fill a significant gap in analytic philosophy of religion.

Astell believed that all individual experiences of suffering would be redeemed by God in virtue of a later, greater good for humanity. Pain is morally justified if it is necessary to ensure wider good. She, like Hays, agreed that those in power should be accountable for failing to improve the conditions of those in lower political and social positions. Astell calls out Christian men in power (specifically) for refusing to help women,

Do they not rather if they are good Christians, bear with infirmities and endeavor to mend them? He then who would object to purpose must show that the Good it may do is not equivalent to the Evil which may attend it; that the Ladies will suffer greater inconveniencies with, than without it, and that it will not in the main be best. Otherwise we shall take liberty to believe that it is humor, covetousness or anything rather than reason which refrains him from approving and promoting it. $(1697,293)$

Reason mitigates against sinful inclinations, which seduce those in power to allow capricious suffering. Reason, then, is central to understanding suffering-it reveals the truth about why people suffer. Telling the truth about suffering and its source threatens to reveal the immoral motives of those who could alleviate harm, but Astell was committed to a theism that prioritized reason and truth-seeking. Women should be taught how to reason, so they could improve morally and grow closer to God. Christian philosophy should lead the way in telling their stories and speaking truth about power structures that create suffering, 
Christian philosophy if it does not so plainly and fully resolve all difficulties, as some curious men may desire, does yet answer them more clearly than any other philosophy does or can. The obscurity it leaves arising chiefly from the necessary limitation of human nature, and imperfection of our present state, which will not allow us to see any otherwise than through a glass darkly, as we are able to bear it. But if this is too hard a task for our titans, it is but reasonable that such professed enemies to imposture, should have the wit and ingenuity to yield to truth, which they allow to be the most powerful thing in the world. $(1709,115)$

Philosophy is suited to the task of redressing injustice because of its pursuit of truth, but the most important truths for Astell were those "rational studies" leading to "charity which edifieth", rather than those dedicated to what she calls "idle amusements" $(1694,64)$. To be worthy of Astell's label of "Christian philosophy", today's narrative theodicies should purpose to reveal substantive truths that edify the hearer. Telling the truth is reason's high calling, and for both Mary Astell and Mary Hays, the result of reason's calling is to help the thinker become closer to God. Narrative theodicies, as epistemic engagements, should help the hearer understand God's goodness and power in relation to suffering. Astell valued the rigor required by rational principles and in her own work paved the way for theodicy by rigorously trying to square evil with an omnipotent Governor of all things, "And if a Wise, Just and Holy Goodness, be better than a tame and careless easiness...then cannot the Great Lord and Governor of all Things, whose knowledge and power are infinite as Himself, remain an idle spectator of the wickedness of the sons of men..." (1709, 119).

Whether in her treatise or narrative forms, Mary Hays also (and more directly) wrestled with reasoning through God's presence to souls in pain. One of her female characters, Emma Courtney, was brazen enough to lament, "what a wretched farce is life!" upon which she expounded $(1796,112)$, "Yet, how am I sure that there is a God-is he wise-is he powerful-is he benevolent? If he be, can he sport himself in the miseries of poor, feeble, impotent, beings, forced into existence, without their choice-impelled, by the iron hand of necessity, through mistake, into calamity?" 12 The role of reason is similar in their pursuit of answers, though the Unitarian nature of Hays's theology led her to a different conclusion than Astell about the reason for suffering. For Astell, we suffer as part of an eschatalogically just world; for Hays, we suffer because of despots but rely on God to help us emerge through our suffering. The way a sufferer feels was much more significant to Hays than Astell to bring the sufferer to belief about divine benevolence. Rather than salvation being the reward for sound opinions, Hays suggested, "After having bewildered ourselves amid systems and theories, religion returns to the susceptible mind as a sentiment rather than as a principle" $(1796,53)$. Narratives, as a conduit

\footnotetext{
12 Hays pushed the envelope again with her protagonist in Emma Courtney; though not a rape victim, Emma was a prostitute's daughter, who was disgraced for her mother's position and was abandoned to be dependent on men for her survival.
} 
to communicating lived experiences (and their feelings, emotions, passions, doubts, and distractions) can direct a susceptible mind to religious sentiments about an evil world and God's place in it.

Another feature of successful narrative theodicy is that it should place the hearer in a better epistemic position than they were prior to the narrative. If theodicy is a knowledge-based philosophical tool (in which the agent who engages with the argument gains knowledge), then those who listen to narrative theodicies should gain truth about evil and God through the stories. Non-propositional truths should be communicated by the stories so the hearer gains access to knowledge about God. ${ }^{13}$ Astell explained the significance of reason and truth-telling for the hearer is that truth positively shapes the hearer's will,

"Especially since the will is blind, and cannot choose but by the direction of the understanding; or to speak more properly, since the Soul always wills according as she understands, so that if she understands amiss, she wills amiss....What is it but the want of an ingenious education, that renders the generality of feminine conversations so insipid and foolish and their solitude so unsupportable?" $(1697,48)$

The goal of the education Astell advocated for in Serious Proposal was, ultimately, moral-that women would ultimately understand divine goodness and thereby make virtuous decisions. Women should be developed as epistemic agents so they can gain wisdom, elect more worthy choices, and point the soul to God. ${ }^{14}$ In a recent paper exploring Astell's view of epistemic injustice, A. Samantha Forbes explains that engrained cultural habits (systems, structures, and customs) in Astell's time could prevent women from having the "interpretive resources" needed to actually understand and manage information. Depriving women of education is a result of targeting women, such that "the lack of resources is not collective, but in the targeted group because the injustice is brought about by and maintains their poor epistemic position" $(2019,793)$. Astell argued that, despite women being kept in intentionally-low social, political, and epistemic positions, women's natural reason sought understanding. But in a time in which women were targeted socially as a group which should not be educated, Astell relied on appeals to (ostensibly) Christian men to view women as having the same souls as men-souls whose interpretive resources require intellectual and moral cultivation. Further substantive harms result if Christian men ignore these truths, "For since God has given women as well as men intelligent Souls, why should they be forbidden to improve them?...Being the Soul was created for the contemplation of Truth as well as for the fruition of Good, is it not as cruel and unjust to preclude Women from the knowledge of the one, as well as the enjoyment of the other?" $(1694,80)$.

\footnotetext{
${ }^{13}$ Recall Stump believes this is the primary advantage of narratives over arguments for theodicy.

${ }^{14}$ To those who wonder why Astell solely focused on improving the epistemic status of women, Astell said, "Custom and the dignity of his sex give authority....Since he is the Man, by which the very word Custom would have us understand not only greatest strength of body, but even greatest firmness and force of mind..." (1700, 49 and 54).
} 
If women are not allowed the interpretive resources to tell their stories and understand others' stories, it would be easy to see how narrative theodicy could fail to communicate and demonstrate God's presence in suffering to women who suffer. Without understanding, narrative theodicy would not put the sufferer in a better epistemic position. It is insufficient for those in privileged social, political, or epistemic roles to be able to infer theological truth from the narrative. A purpose of narrative theodicy is to relate the grieving (the maligned, the outcast) to God through the narrative, and if the sufferer lacks the ability to understand the story, she lacks the ability to relate to God through it.

Though Astell and Hays shared beliefs about God and injustice, Hays more progressively and directly confronted the problem of evil and suggested theists had at least an experiential advantage over others to think through the problem of suffering. If theists experienced the transformation of their own vices into virtues in ordinary life, they were more likely to view suffering longitudinally. Narrative theodicies should help the theist (at least) do the same. Hays suggested that evil will ultimately be uprooted and transformed, through the eternal process of creation and redemption, "from the infinite goodness of the Parent of the universe, I expect the ultimate restoration of all his intelligent offspring, when purified and refined by sufferings.... And momentary will be all limited affliction, though extending thousands of years beyond the duration of this earth, in comparison of eternity" $(1798,169)$. Unsuspecting readers might infer from this snapshot from Hays that she advocates kenotic suffering (or, the view that suffering purifies and redeems the believer). The opposite is true. We are not redeemed through suffering, but the entire created order will be transformed into something good and pure as part of the created order. Restoration is part of an eschatological ideal but because redemption is not the point of human suffering, it should not be the point of narrative theodicy.

The point of "Christian philosophy" instead should be to rectify systems of injustice, now, and to do so while providing an account of divine perfection within a world in which there are horrendous evils. The laws instituted by men were systemically, intentionally oppressive, on Hays's view, “Law completes the triumph of injustice. The despotism of man rendered me weak, his vices betrayed me into shame, a barbarous policy stifled returning dignity, prejudice robbed me of the means of independence, gratitude ensnared me in the devices of treachery, the contagion of example corrupted my heart, despair hardened and brutality rendered it cruel" $(1796,68)$. The triumph of injustice through unjustifiable oppression is evil; it perverts what Hays believed social and political structures should be. Even virtue, if brought about by unworthy means, stands against reason and the just version of the world we were all created to participate in. She noted, "If the reverse of this were true-how imperfect and how unworthy of the great Author of all good and all perfection, were the moral government of this sublunary world!" $(1798,157)$. Anyone who suggests that present suffering is ordained by God is confused by the perversion of the moral and legal orders by evil men.

Theists, too, could equivocate between the actions of immoral people in power with actions of a perfect Divine being, but Hays still contended that it would be impossible-blasphemous-to imagine that God could be the source of evil, or 
"that Infinite purity could implant in the creatures of his power a natural propensity to evil" (1793, 208-9). Though Hays largely sought to avoid questions about the necessity of evil, she explicitly warned against "robbing the Supreme being of his attributes" or suggesting there were evil intentions that could counteract "the benevolent designs of the Deity" $(1793,168)$. Rather, for Hays, God is present in suffering just as he is present in the ultimate transformation of the created order. Narratives should be honest in their depictions of suffering (as Hays was in Victim and Emma Courtney). So, the experiences in the narrative should relate to those who are in pain and should richly demonstrate the presence of God in suffering-that God remains in suffering to carry the weight of it, to commend us towards virtue, and to fulfill the creative and restorative purposes for human systems of morality and legality (Hernandez 2016, 123).

Mary Astell and Mary Hays, together, help us clarify the goals of narrative theodicy beyond relating the hearer to the story and demonstrating divine perfection. Narrative theodicy should, specifically, explicate truth about suffering and its source, reveal truth about the problem of evil, and place the oppressed in a better epistemic position than they were. Results of these aspects of narrative theodicy include that narrative theodicies will provide a vision for eschatology, marry an account of suffering with divine perfection, and rectify systems of injustice. The work of these two Marys delineates the feminist function of narrative theodicy for contemporary philosophers of religion by focusing on concrete, lived suffering and restoring those who hurt-but can it help assuage the difficulties for the Mary of Bethany story as narrative theodicy?

\section{Something about Mary}

Analytic philosophers of religion are responding to the call of feminists to tie the problem of evil to lived expressions of suffering. Those responses include the project of narrative theodicy. Eleonore Stump's narrative theodicies include those stories of those who suffered greatly, as well as those who suffer in more ordinary ways, such as Mary of Bethany. Delving into her narrative helps us explore the contours of narratives generally to succeed as theodicy. The banality of Mary's suffering alone does not preclude hers from functioning as theodicy. Understood without the lens of early modern feminist philosophers of religion, the challenges for the Mary of Bethany story to serve as theodicy are steep, and include: that Mary held an epistemically privileged position that could be difficult for contemporary sufferers to understand and relate; that through the banality of her suffering, we as readers do not see her lose faith; and that her story could not sufficiently demonstrate the power of God in situated expressions of suffering. Early feminists Mary Astell and Mary Hays bolster contemporary analytic feminist attempts to use narratives as theodicies by framing our expectations for the endeavor.

If we take feminism's call for concrete engagement with suffering seriously, Astell and Hays work suggests that narrative theodicy should speak directly to the plight of those who suffer, and should allow the powerless, miserable, unprivileged, 
and oppressed to have access to religious knowledge of the relationship between God and the one in pain. Mary of Bethany suffers ordinarily, over time, and her grief is construed by Stump as a loss of faith. Absent the early modern framework for narrative theodicy, Mary of Bethany's suffering is contextualized within a lifetime of service to God. Her story is one of someone who has privileged access to Christ (and so, is potentially unrelatable), yet is powerless to act (and so, relatable to many women throughout history). Mary Astell and Mary Hays shape our view of Mary of Bethany's story as a case study-to succeed as narrative theodicy, the sufferer who hears it must understand God's presence during suffering, as well as the human impetus to right current moral wrongs and social evil as the source of suffering. The project of narrative theodicy - and the case study of Mary of Bethany, specificallyis strengthened by turning towards theist feminists who were dedicated to identifying and addressing concrete harms that disproportionately negatively impacted women. Mary of Bethany (as a theodical model) should assert or find her dignity, which may require her to express anger at her low social standing, as occurred with Hays's own Mary Raymond, "I demand my liberty this moment; I insist upon being suffered to depart. No one has a right to control me. I will appeal to the tribunal of my country; I will boldly claim the protection of its laws, to which thou art already amenable" $(1799,117)$. Though Mary Raymond does not suffer analogously to Mary of Bethany (Raymond as a rape victim, Mary of Bethany as chastised friend of Jesus), both suffer as a result of being marginalized by the prejudices of their society. Mary of Bethany does see injustices remedied in a way Raymond cannot: Christ directly rebukes those who criticize her for anointing him; at a different moment, he weeps along with Mary and Martha when Lazarus dies; and after they admonish him for not coming when they initially called for him, Christ raises Lazarus from the dead. Christ's interventions address Mary of Bethany's pain in the ways Astell and Hays could only have hoped.

Additionally, read through the framework of Astell and Hays, Mary of Bethany's sorrow can also be understood as ensconced within a vision for eschatology contextualized by Christ's death and resurrection, as a story for God's own glorification. So, these goals of narrative theodicy could be realized within the context of the story itself (even if divorced from the lived experiences of many who would look to the story for theodical meaning today). The story also could be read to explicate truth about suffering and its source (by showing that God cares about Mary's banal suffering), even if it remains unclear that the story puts the hearer in an improved epistemic position. On one hand, Christ is moved on a personal level by Mary's ordinary grief-a hearer who might identify with Mary might relate to his level of care for her. On the other hand, those who suffer might not relate to someone whose family was so close to Jesus that he raised their brother from the dead. The case study raises the question as to whether someone who lost faith through their suffering would relate to Mary of Bethany, and then walk away from the story with the non-propositional knowledge that Stump gains from it.

Some feminist critics contend that biblical narratives can never be a theodical source because Scripture fails to speak to those who truly suffer from (especially) atrocious harms, nor from the perspective of those who suffer, since the biblical authors were males who wrote from positions of social and epistemic 
privilege. ${ }^{15}$ It is possible, after all, to accept that biblical narratives could be relatable and still reject that they explain God's goodness and love. But, the project of putting Mary Astell and Mary Hays into conversation with Stump's narrative theodicy of Mary of Bethany does more than articulate how narratives can engage with concrete suffering. It provides guidelines for theodical narratives to effectively communicate divine perfection to the sufferer in better ways-to provide access to religious knowledge that the powerless, unprivileged, and oppressed might not have otherwise had.

\section{References}

Abbott, Curtis. 2011. "Seeking Lost Souls and Exorcising Demons: Christological CoNarration in Psychoanalytic Storytelling," Journal of Spirituality in Mental Health 13(2): 92-137.

Adams, Marilyn McCord. 1999. Horrendous Evils and the Goodness of God. Cornell University Press.

Astell, Mary; Judith Drake. 1696. An essay in defence of the female sex, For A. Roper \& E. Wilkinson; R. Clavel, from the University of North Carolina-Greensboro's "Woman's Collection".

Astell, Mary. 1709. Bart'lemy Fair: Or, an Enquiry after Wit: in which Due Respect is Had to a Letter concerning Enthusiasm. R. Wilkin.

.1705. The Christian Religion, As Profess'd by a Daughter of the Church of England. In a Letter to the Right Honourable, T.L. C.I. R. Wilkin.

1694. A Serious Proposal To the Ladies, For the Advancement of their true and greatest Interest. By a Lover of Her Sex. K.Wilkin. 1697. A Serious Proposal To the Ladies, Part II, Wherein a method is offer'd for the improvement of their minds. K.Wilkin.

. 1700/1997. "Some reflections upon marriage." In Astell: Political Writings, edited by Patricia Springborg. Cambridge University Press.

Baffes, Melanie. 2016. Love, Loss, and Abjection: The Journey of New Birth in the Gospel of John. Wipf \& Stock.

Bar On, Bat-Ami. 2007. “Terrorism, Evil, and Everyday Depravity.” In Feminist

\footnotetext{
${ }^{15}$ Claudia Card makes this point in both of her books (2002 and 2010), but also see (for example) Jaggar $(2007,219-227)$.
} 
Philosophy and the Problem of Evil. Edited by Robin M. Schott. University of Indiana and Hypatia, Inc.

Beavis, Mary Ann. 2013. "Mary of Bethany and the Hermeneutics of Remembrance." The Catholic Biblical Quarterly 25: 739-755.

Card, Claudia. 2002. The Atrocity Paradigm. Oxford University Press. 2010. Confronting Evils: Terrorism, Torture, Genocide. Cambridge University Press.

Forbes, Allauren Samantha. Fall 2019. "Mary Astell on Bad Custom and Epistemic Injustice," Hypatia 34(4): 777-801.

Hays, Mary. 1793. Letters and Essay: Moral and Miscellaneous. Knott. 1796/2000. Memoirs of Emma Courtney. Edited by Marilyn L. Brooks. Broadview.

Hays, Mary. 1799. A Victim of Prejudice. J. Johnson.

Hernandez, Jill. 2016. Early Modern Women and the Problem of Evil: Atrocity \& Theodicy. Routledge.

Jaggar, Alison. 2007. "Naming Terrorism as Evil.” In Feminist Philosophy and the Problem of Evil. Edited by Robin M. Schott. University of Indiana and Hypatia, Inc.

Kent, J. Grenville. 2010. "Mary Magdalene, Mary of Bethany and the Sinful Woman of Luke 7: The Same Person?" Journal of Asia Adventist Seminary. 13(1): 13-28.

Lindley, Keith. 2016. A Narrative Theodicy. PhD diss., Dallas Theological Seminary.

Oliver, Sarah Ann. 2007. The Rape of Mary Raymond : a radical view of rape in Mary Hays's "The Memoirs of Emma Courtney" and "The Victim of Prejudice." University of Plymouth Research Theses 04, http://hdl.handle.net/10026.1/716.

Perry, Ruth, 1986. The Celebrated Mary Astell: an Early English Feminist. University of Chicago Press.

Platt, Elizabeth E. 1977. "The Ministry of Mary of Bethany," Theology Today. 34(1): 29-39.

Schott, Robin May. 2009. "War Rape and the Political Concept of Evil," In Evil, Political Violence, and Forgiveness, edited by Kathryn Norlock. Lexington. 
Stump, Eleonore. 2001. "Second-person Accounts and the Problem of Evil."Revista Portuguesa de Filosofia. 57: 745-771. 2010. Wandering in Darkness. Oxford University Press.

Tillich, Paul. 1959. Theology of Culture. Oxford University Press.

van Inwagen, Peter. Fall 1988. “The Magnitude, Duration, and Distribution of Evil: A Theodicy." Philosophical Topics. Volume XVI(2): 161-187.

Ward, Ian. 2009. "The Prejudices of Mary Hays." International Journal of Law in Context. 5(2): 131-146.

Yandell, Keith. 2001. Faith and Narrative. Oxford University Press.

Zeigler, Michael W. 2017. Christian Hope among Rivals: How Life-Organizing Stories Anticipate the End of Evil. Wipf and Stock Publishers. 